Opinion

\title{
Diagnosis of Dysferlinopathies
}

\author{
Fernández-Simón E, Diaz-Manera J, Gallardo E and De Luna N* \\ Neuromuscular Diseases Laboratory, Universitat Autonoma de Barcelona, Spain
}

Submission: March 18, 2019; Published: April 22, 2019

*Corresponding author: Noemí De Luna, Neuromuscular Diseases Laboratory, IIB Sant Pau, Universitat Autonoma de Barcelona, Barcelona, Spain and Centro de Investigaciones en red en Enfermedades Raras (CIBERER), Valencia, Spain

\section{Opinion}

Dysferlinopathies are autosomal, recessive allelic muscle disorders produced by mutations in the dysferlin gene (DYSF) [1]. The disease has different phenotypes including limb girdle 2B, Miyoshi myopathy or distal anterior compartment myopathy among others [2]. Dysferlin is located at the membrane of the muscle fiber and its main function is related with membrane repair after damage. However, dysferlin has also been involved in other processes including intracellular signaling or myoblast differentiation. Dysferlin is expressed in other tissues such as monocytes, heart, kidney and placenta where its function is not completely known $[3,4]$.

Diagnosis of patients with dysferlinopathies can be challenging due to the phenotypic variability and the size of the gene. DYSF is one of the biggest human genes. It spans a genomic region of $>150 \mathrm{~kb}$ and contains 55 exons that encode a $237 \mathrm{kDa}$ protein composed of 2080 amino acids. More than 250 variants have been identified, and there are not hotspots. Therefore, Sanger sequencing is a time consuming and cost-effective method for mutational screening. Moreover, in 15 to $20 \%$ of the patients only one mutation is found and in up to $5 \%$ of the patients no mutations are detected. In these cases, the analysis of protein expression can be useful either in the muscle biopsy or in other available tissues $[5,6]$.

Immunohistochemistry (IHC) is a useful method to assess a reduction or absence of dysferlin in skeletal muscle. However, IHC analysis can be misleading because dysferlin can be aggregated in the cytoplasm and reduced in the sarcolemma of necrotic or regenerating fibers [7]. Also, patients with missense mutations that allow synthesis of residual protein may show a positive staining by IHC [8]. On the other hand, dysferlin forms a complex with other proteins to perform its function. Mutations in those proteins can disturb the localization of dysferlin, leading to a secondary deficiency $[9,10]$. For this reason, the diagnosis of dysferlinopathies can not be made based only in dysferlin expression by IHC. Western-Blot (WB) can be useful to confirm the diagnosis [11].

WB analysis of muscle biopsy is a method more reliable since it allows quantification of the protein and therefore discriminates between patients and carriers of one mutation in DYSF $[11,12]$. The limitations of WB analysis in skeletal muscle are muscle tissue availability and the invasiveness of the surgical procedure to obtain the sample. An alternative to the muscle biopsy is the analysis of dysferlin expression in peripheral blood CD14+ monocytes [13]. Gallardo and collaborators [8], performed a comparative study in 17 dysferlinopathy patients and 21 patients with other neuromuscular disorders and demonstrated that dysferlin expression in monocytes mirrors that in skeletal muscle using WB. However, IHC of dysferlin in skeletal muscle biopsies can be misleading in some cases such as in patients with calpainopathy. Moreover, De Luna et al. [14] also presented the usefulness of peripheral blood monocytes mRNA as a source to study mutations in the DYSF. In yet another study by Luna et al. [15] dysferlin expression in monocytes was quantified in 20 dysferlinopathy patients, 53 carriers and 80 healthy subjects. They showed that dysferlin levels lower than $23 \%$ were found in patients with two mutations in the DYSF, while levels between $24.5 \%$ and $78.2 \%$ were found in healthy individuals and carriers of a single mutation in the DYSF.

In summary, quantification of dysferlin protein in PBM is an easy non-invasive tool that can be useful to diagnose patients with dysferlinopathy, especially in those cases in whom only one mutation is found. At present, next generation sequencing studies may report either a single known pathogenic mutation or new variants of unknown significance. The existence of an easy diagnostic tool such as the blood-based monocyte test can be very useful to support the diagnosis of dysferlinopathy.

\section{References}

1. Passos-Bueno MR, Bashir R, Moreira ES, Vainzof M, Marie SK, et al (1995) Confirmation of the $2 p$ locus for the mild autosomal recessive limb-girdle muscular dystrophy gene (LGMD2B) in three families allows refinement of the candidate region. Genomics 27(1): 192-195.

1. Bashir R, Strachan T, Keers S, Stephenson A, Mahjneh I, et al. (1994) A gene for autosomal recessive limb-girdle muscular dystrophy maps to chromosome 2p. Hum Mol Genet 3(3): 455-457.

2. Cenacchi G, Fanin M, De Giorgi LB, Angelini C (2005) Ultrastructural changes in dysferlinopathy support defective membrane repair mechanism. J Clin Pathol 58(2): 190-195. 
3. A Amato, RH Brown (2011) Dysferlinopathies. Handb Clin Neurol 101: 111-118.

4. Santos R, Oliveira J, Vieira E, Coelho T, Carneiro AL, et al. (2010) Private dysferlin exon skipping mutation (c.5492G\&gt;A) with a founder effect reveals further alternative splicing involving exons 49-51. J Hum Genet 55(8): 546-549.

5. Wenzel K, Carl M, Perrot A, Zabojszcza J, Assadi M, et al. (2006) Novel sequence variants in dysferlin-deficient muscular dystrophy leading to mRNA decay and possible C2-domain misfolding. Hum Mutat 27(6): 599-600.

6. Piccolo F, Moore SA, Ford GC, Campbell KP (2000) Intracellular accumulation and reduced sarcolemma expression of dysferlin in limb--girdle muscular dystrophies. Ann Neurol 48(6): 902-912.

7. Gallardo E, de Luna N, Diaz-Manera J, Rojas-García R, GonzalezQuereda L, et al. (2011) Comparison of dysferlin expression in human skeletal muscle with that in monocytes for the diagnosis of dysferlin myopathy. PLoS One 6(12): e29061.

8. Anderson LV, Davison K, Moss JA, Young C, Cullen MJ, et al. (1999) Dysferlin is a plasma membrane protein and is expressed early in human development. Hum Mol Genet 8(5): 855-861.

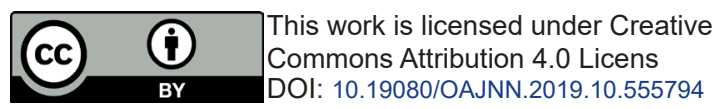

9. Matsuda C, Aoki M, Hayashi YK, Ho MF, Arahata K, et al. (1999) Dysferlin is a surface membrane-associated protein that is absent in Miyoshi myopathy. Neurology 53(5): 1119-1122.

10. De Luna N, Gallardo E, Soriano M, Dominguez-Perles R, de la Torre C, et al. (2006) Absence of dysferlin alters myogenin expression and delays human muscle differentiation in vitro. J Biol Chem 281(25): 17092 17098.

11. M Ho, Post CM, Donahue LR, Lidov HG, Bronson RT, et al. (2010) Disruption of muscle membrane and phenotype divergence in two novel mouse models of dysferlin deficiency. Hum Mol Genet 13(18): 1999-2010.

12. D McKenna-Yasek, E Gallardo, N De Luna, I Illa, RH Brown, M Ho (2002) A novel, blood-based diagnostic assay for limb girdle muscular dystrophy 2B and miyoshi myopathy. Ann Neurol 51 (1): 129-133.

13. De Luna N, Díaz-Manera J, Paradas C, Iturriaga C, Rojas-García R, et al. (2012) $1 \alpha, 25(\mathrm{OH})(2)$-Vitamin D3 increases dysferlin expression in vitro and in a human clinical trial. Mol Ther 20(10): 1988-1997.

14. De Luna N, Freixas A, Gallano P, Caselles L, Rojas-García R, et al. (2007) Dysferlin expression in monocytes: A source of mRNA for mutation analysis. Neuromuscul Disord 17(1): 69-76.

\begin{tabular}{l} 
Your next submission with Juniper Publishers \\
will reach you the below assets \\
- Quality Editorial service \\
- Swift Peer Review \\
- Reprints availability \\
- E-prints Service \\
- Manuscript Podcast for convenient understanding \\
- Global attainment for your research \\
- Manuscript accessibility in different formats \\
( Pdf, E-pub, Full Text, Audio) \\
- Unceasing customer service \\
Track the below URL for one-step submission \\
https://juniperpublishers.com/online-submission.php \\
\hline
\end{tabular}

